Original Research Paper

\title{
Struktur Komunitas Makroalga sebagai Indikator Ekologi Ekosistem Perairan pada Kawasan Konservasi Laut Daerah di Gili Sulat Lombok Timur
}

\author{
Susanty Ariani ${ }^{1}$, Agil Al Idrus ${ }^{1 *}$, Lalu Japa ${ }^{1} \&$ Didik Santoso ${ }^{1}$ \\ ${ }^{1}$ Program Studi Pendidikan Biologi FKIP Universitas Mataram, Jalan Majapahit No. 62, Mataram, Indonesia
}

\author{
Riwayat artikel \\ Received : 11 Februari 2020 \\ Revised : 7 April 2020 \\ Accepted : 21 April 2020 \\ Published : 22 April 2020 \\ *Corresponding Author: \\ Agil Al Idrus, \\ Program Studi Pendidikan \\ Biologi FKIP Universitas \\ Mataram, Mataram Nusa \\ Tenggara Barat, Indonesia. \\ Email: agilalidrus@gmail.com
}

\begin{abstract}
Abstrak: Makroalga adalah salah satu sumber daya alam yang memiliki nilai ekonomis tinggi. Keragaman makroalga kawasan daerah tropis sangat tinggi, tidak terkecuali di daerah intertidal Gili Sulat. Keberadaan komuditas ini di Gili Sulat belum banyak diketahui. Penelitian ini bertujuan mendiskripsikan keragaman spesies makroalga sebagai indikator ekologi ekosistem perairan di kawasan konservasi laut daerah Gili Sulat Lombok Timur. Pengumpulan data penelitian makroalga dengan metode kuadrat $(1 \times 1 \mathrm{~m})$ yang disebar pada tiga stasiun pengamatan. Analisis data untuk indeks keanekaragaman spesies menggunakan indeks Shannon-Wiener, indeks keseragaman spesies menggunakan indeks Evennes, indeks dominansi menggunakan indeks Simpson dan analisis hubungan makroalga dengan faktor lingkungan menggunakan uji Korelasi Product Moment. Hasil penelitian menemukan 11 spesies makroalga, dan 7 spesies dari kelas Chlorophyceae dan 4 spesies dari kelas Phaeophyceae. Selain itu, spesies yang memiliki nilai kepadatan tertinggi adalah Halimeda opuntia sebesar 18.519 rumpun/ha. Sementara itu, hasil analisis indkes keanekaragaman spesies dari semua spesies yang temukan berada dalam kategori sedang dengan nilai pada stasiun I adalah 1,00, stasiun II adalah 1,36 ; dan stasiun III adalah 1,59. Selanjutnya, nilai keseragaman spesies berdasarkan hasil perhitungan diperoleh pada stasiun I adalah 0,53, stasiun II adalah 0,65 dan Stasiun III adalah 0,85 . Oleh karena itu, spesies makroalga pada stasiun III memiliki tingkat keseregaman yang paling tinggi dibandingkan dua stasiun lain (I dan II) di lokasi studi. Kesimpulan dari penelitian adalah makroalga dapat menjadi indikator ekologi untuk menilai perubahan ekosistem pada kawasan konservasi laut daerah di Gili Sulat Lombok Timur Nusa Tenggara Barat.
\end{abstract}

Kata kunci: Makroalga, Keanekaragaman dan Gili Sulat.

Abstract: Macroalgae is one of the natural resources that has high economic value. The diversity of macroalgae in the tropics is very high, not least in the intertidal area of Gili Sulat. The existence of this community in Gili Sulat is not well known. This study aims to describe the diversity of macroalgae species as an indicator of the ecology of aquatic ecosystems in regional marine conservation areas in Gili Sulat, East Lombok. Research data collection for macroalgae using the quadratic method (1 x $1 \mathrm{~m}$ ) spread across three observation stations. Data analysis for the species diversity index uses the Shannon-Wiener index, the species uniformity index uses the Evennes index, the dominance index uses the Simpson index and the analysis of the relationship of macroalgae with environmental factors using the Product Moment Correlation test. The results found 11 species of macroalgae, and 7 species of the class Chlorophyceae and 4 species of the class Phaeophyceae. In addition, the species that has the highest density value is Halimeda opuntia of 18,519 clumps / ha. Meanwhile, the results of the analysis of the species diversity index of all species found were in the medium category with the value at station I being 1.00 , station II being 1.36; and station III is 1.59. Furthermore, the species uniformity value based on the calculation results obtained at station I is o, 53, station II is 0.65 and Station III is 0.85 . Therefore, the macroalgae species at station III have the highest level of uniformity compared to the other two stations (I and II) at the study location. The conclusion from the study is that macroalgae can be an ecological indicator to assess 
ecosystem changes in the marine conservation area in Gili Sulat, East Lombok, West Nusa Tenggara.

Keywords: Macroalgae, Diversity and Gili Sulat

\section{Pendahuluan}

Perairan Indonesia dengan luas wilayah laut 5,8 $\mathrm{km}^{2}$ (KKP, 2016) memiliki potensi kekayaan laut yang sangat besar untuk dimanfaatkan. Salah satu yang sering ditemukan adalah makroalga. Makroalga atau yang lebih dikenal dengan rumput laut (seaweed) merupakan Protista menyerupai tumbuhan yang hidupnya melekat atau menancap pada substrat dasar perairan (Raven et al., 1992 dalam Rahmandi, 2019).

Gili Sulat berada di Desa Sugian, Kecamatan Sambelia, Lombok Timur yang dilindungi berdasarkan SK Bupati No. 188.45/452/KP/2004, tanggal 16 September 2004 (Al Idrus, 2014). Perairan Gili Sulat termasuk ke dalam Kawasan Konservasi Perairan Daerah (KKPD) (KKP, 2013) atau Marine Protected Areas (MPAs) dengan tujuan memastikan pengelolaan perikanan dan sumberdaya alam yang berkelanjutan dan bertanggung jawab atas kesejahteraan masyarakat (Lazuardi, 2013). Di kawasan ini juga terdapat Komite Pengelolaan Perikanan Laut (KPPL) yang bertujuan untuk mengenalkan pendekatan pengelolaan sumberdaya perikanan pesisir partisipatif dengan menggunakan hukum setempat dan mengatasi serta menyelesaikan masalah praktik penangkapan yang merusak (Bachtiar, 2005).

Potensi besar yang dimiliki Gili Sulat menjadikan pulau ini salah satu lokasi yang banyak dilakukan penelitian diantaranya, Komunitas Plankton Pada Perairan Habitat Mangrove (Aini et al., 2018), Potensi Vegetasi dan Arthropoda di Kawasan Mangrove Gili Sulat (Al Idrus et al., 2015), Keanekaragaman Jenis Burung di Kawasan Mangrove Gili Sulat (Hadiprayitno et al., 2014), dan Kekhasan Morfologi Spesies Mangrove Di Gili Sulat (Al Idrus et al., 2014).

Karnan et al., (2018) menjelaskan bahwa secara umum, informasi tentang sumberdaya laut di Pulau Lombok termasuk makroalga masih sangat terbatas. Beberapa penyebab terjadinya kondisi ini adalah kajian dan laporan tentang keberadaan makroalga di wilayah ini masih sangat terbatas. Padahal secara ekologis komunitas makroalga memiliki peranan penting bagi komunitas lainnya. Sebagaimana dilaporkan oleh Karnan et al. (2016), bahwa secara ekologis, kompleksitas yang dibentuk oleh komunitas Sargassum ini memiliki fungsi yang sama dengan terumbu karang, padang lamun, dan mangrove yaitu sebagai daerah asuhan (nursery ground), tempat mencari makan (feeding ground), tempat memijah (spawning ground) dan meletakkan telur bagi berbagai macam biota laut seperti ikan dan cumi-cumi. Keberadaan komunitas Sargassum ini dapat pula meredam kecepatan arus sehingga berperan penting dalam penyelamatan pantai. Selain itu komunitas Sargasum dapat berperan untuk meningkatkan nilai biodiversity dan peran ini sangat penting seperti peran ekologi lamun. Namun demikian, keberadaan makroalga dari aspek ekologi sebagai komponen biotik pada ekosistem perairan, khususnya pada kawasan konservasi laut daerah Gili Sulat belum ada penelitiannya. Oleh karena itu dibutuhakan penelitian berkaitan dengan kekayaan spesies makroalga. Tujuan dari penelitian ini adalah mendiskripsikan keragaman spesies makroalga sebagai indikator ekologi ekosistem perairan di kawasan konservasi laut daerah Gili Sulat Lombok Timur.

\section{Bahan dan Metode}

\section{Waktu dan Tempat}

Penelitian dilakukan pada bulan September dan pengambilan data menggunakan metodekuadrat. Stasiun pengamatan yang digunakan dalam penelitian ini sebanyak 3 stasiun dengan jarak antarstasiun $100 \mathrm{~m}$ dengan panjang transek $100 \mathrm{~m}$ dan disesuaikan dengan batas aman perairan. Posisi transek diletakkan secara tegak lurus dengan garis pantai mengarah ke laut. Penentuan titik transek dan koordinat ditentukan dengan menggunakan aplikasi Google Earth dan akan dicocokkan dengan Global Positioning System (GPS) pada saat di lokasi penelitian (Tabel 1).

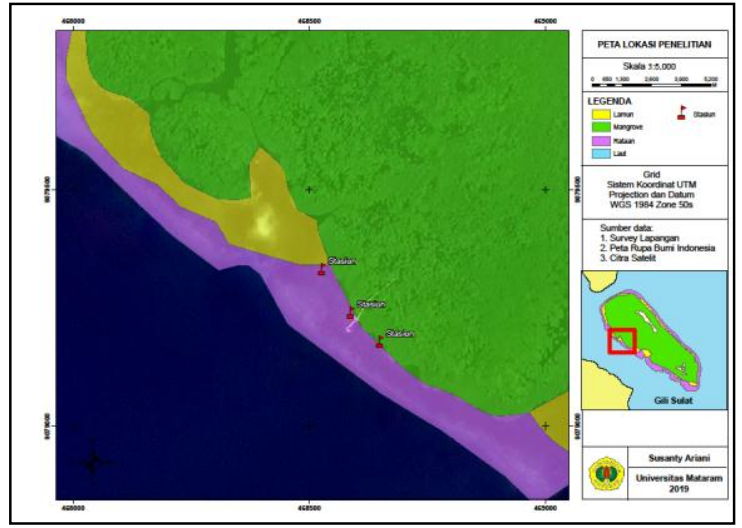

Gambar 1. Peta Lokasi Penelitian. 
Tabel 1. Titik Koordinat Stasiun Pengamatan.

\begin{tabular}{lll}
\hline Stasiun & \multicolumn{2}{c}{ Koordinat } \\
\cline { 2 - 3 } & Lintang & $\begin{array}{l}\text { Bujur } \\
\text { Timur }\end{array}$ \\
\hline I & $8^{\circ} 19^{\prime} 49^{\prime \prime}$ 'S & $116^{\circ}$ \\
& & $42^{\prime} 55^{\prime} \mathrm{E}$ \\
II & $8^{\circ} 19^{\prime} 47^{\prime}$ 'S & $116^{\circ}$ \\
& & $42^{\prime} 53^{\prime \prime} \mathrm{E}$ \\
III & $8^{\circ} 19^{\prime} 44^{\prime \prime} \mathrm{S}$ & $116^{\circ}$ \\
& & $42^{\prime} 51^{\prime \prime} \mathrm{E}$ \\
\hline
\end{tabular}

Metode pengambilan data penelitian menggunakan kuadrat yang berbentuk persegi dengan ukuran 1 x $1 \mathrm{~m}$. Setiap kuadrat penelitian memiliki 4 kisi yang berukuran 50 x $50 \mathrm{~cm}$. Kuadrat diletakkan pada setiap rentang $10 \mathrm{~m}$ garis transek dan dimulai dari titik 0 garis transek. Selain itu dilakukan pengambilan data lingkungan yang meliputi: salinitas, suhu dan $\mathrm{pH}$ perairan. Parameter magroalga yang menjadi objeks penelitian adalah jumlah spesies dan jumlah individu/spesies. Aanalisis data penelitian menggunakan teknik analisis statistic diskriptif. Selain itu, dilakukan analisis data yang meliputi Kepadatan (D), Indeks Keanekaragaman (H'), Indeks Keseragaman (E), Indeks Dominansi (D). Formula yang digunakan untuk tiap analisis adalah:

1. Kepadatan (D)(Brower and Zar, 1977 dalam Erliyanda et al., 2017):

$$
D=\frac{\sum N i}{A}
$$

\section{Keterangan:}

$\mathrm{D}=$ Kepadatan setiap spesies

$\mathrm{Ni}=$ Jumlah individu per spesies (jumlah tegakkan rumpun per spesies) yang diperoleh selama penelitian

A = Luas areal yang terukur dengan kuadrat $\left(\mathrm{m}^{2}\right)$

2. Indeks Keanekaragaman (H') Shannon- Wiener (Krebs, 1972):

$$
\mathrm{H}^{\prime}=-\Sigma(P i)\left(\log ^{2} P i\right)
$$

$\mathrm{N}=$ Jumlah total individu

3. Indeks Keseragaman (E) dengan formula Evennes (Krebs, 1972):

$$
E=\frac{H}{H \max }
$$

Keterangan:

H' =Indeks Keanekaragaman

$\mathrm{H} \max =\log \mathrm{S}=$ Banyaknya spesies

Tabel 2. Interpretasi nilai indeks keseragaman spesies.

\begin{tabular}{lcc}
\hline No & Keseragaman & Kategori \\
\hline 1. & $0,00<\mathrm{E}<0,50$ & Rendah \\
2. & $0,50<\mathrm{E}<0,75$ & Sedang \\
3. & $0,75<\mathrm{E}<1,00$ & Tinggi \\
\hline
\end{tabular}

(Hukom, (1996) dalam Palallo, (2013))

4. Indeks Dominansi (D) Simpson (Krebs, 1972):

$$
\mathrm{D}=1-\Sigma(P i)^{2}
$$

Keterangan:

$\mathrm{D}=$ Indeks Dominansi Simpson

$\mathrm{Pi}=\mathrm{n}_{\mathrm{i}} / \mathrm{N}$

$\mathrm{ni}=$ Jumlah individu dari spesies Makroalga ke-i

$\mathrm{N}=$ Jumlah individu seluruh spesies

Jika, $\mathrm{D}=0$, berarti tidak terdapat spesies yang mendominansi

$\mathrm{D}=1$, berarti terdapat spesies yang mendominasi

Selanjutnya, dilakukan Uji korelasi Product Moment (Arikunto, 2018) untuk mengetahui tingkat hubungan antara faktor lingkungan yang diukur dengan populasi makroalga. Pedoman interpretasi koefisien korelasi " $r$ " pearson product moment dapat dilihat pada Tabel 3.

$$
\mathrm{r}_{\mathrm{pm}}=\frac{\mathrm{n}\left(\sum \mathrm{xy}\right)-\left(\sum \mathrm{x}\right)\left(\sum \mathrm{y}\right)}{\sqrt{\left\{\mathrm{n}\left(\left(\sum \mathrm{x} 2\right)-\left(\sum \mathrm{x}\right) 2\right)\right\}\left\{\left(\mathrm{n} \sum \mathrm{y} 2-\left(\sum \mathrm{y}(2)\right\}\right.\right.}}
$$

Keterangan:

$\mathrm{H}^{\prime}=$ Indeks keanekaragaman

$\mathrm{P}=\mathrm{ni} / \mathrm{N}$

$\mathrm{ni}=$ Jumlah individu spesies Ke-i 
Tabel 3. Interpretasi Koefisien Korelasi " $r$ " Pearson Product Moment

\begin{tabular}{ll}
\hline Interval Koefisien & Tingkat Hubungan \\
\hline $0,80-1,00$ & Sangat kuat \\
$0,60-0,799$ & Kuat \\
$0,40-0,599$ & Sedang \\
$0,20-0,399$ & Lemah \\
$0,00-0,199$ & Sangat lemah \\
\hline
\end{tabular}

\section{Hasil dan Pembahasan}

\section{Komposisi Spesies}

Spesies makroalga yang teridentifikasi meliputi total 11 spesies. 7 spesies dari kelas Chlorophyceae dan 4 spesies dari kelas Phaeophyceae. Tujuh kelas Chlorophyceae adalah Ceulepra racemosa, Codium sp., Halimeda discoidea, Halimeda macroloba, Halimeda opuntia, Halimeda tuna, dan Neomeris annulata. Sedangkan spesies dari kelas Phaeophyceae terdiri dari Dictyota dichotoma, Hydroclanthrus clathratus, Padina australis dan Sargassum sp.

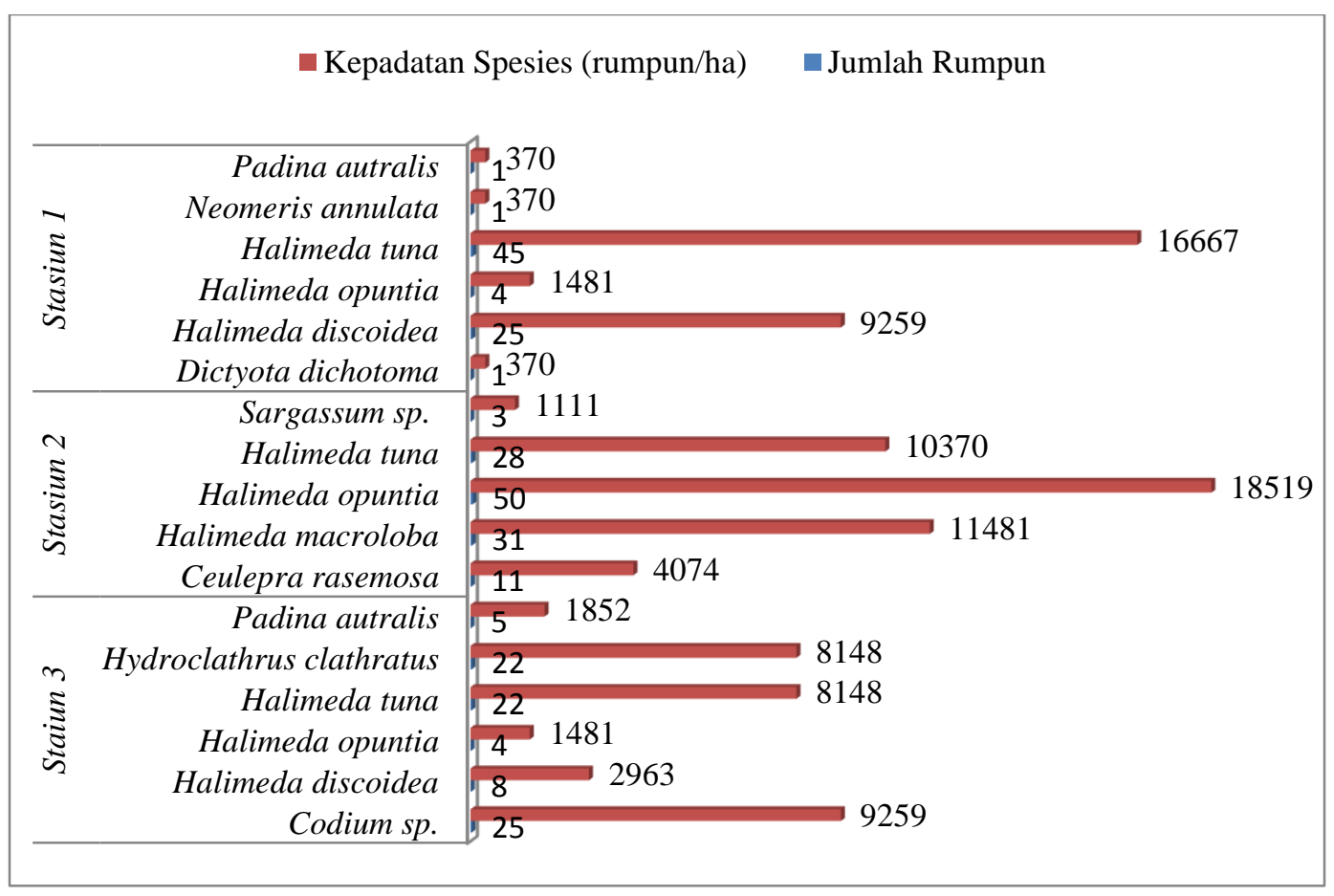

Gambar 2. Kepadatan dan Jumlah Rumpun Makroalga pada lokasi penelitian

Gambar 2 memperlihatkan kepadatan individu pada stasiun 1 dan 2 menunjukkan bahwa kepadatan tertinggi diduduki olehHalimeda sp. dengan masingmasing sebesar18.519 rumpun/ha dan 16.667 rumpun/ha. Hasil ini menunjukkan bahwa frekuensi kehadiran spesies Halimeda sp. merupakan yang paling banyak dibandingkan dengan yang lainnya. Hal ini dikarenakan substrat yang berpasir, yang merupakan habitat bagi alga hijau terutama Halimeda sp. Sedangkan pada stasiun 3, kepadatan tertinggi diperoleh oleh spesies Codium sp. dengan nilai 9.259 rumpun/ha. Keberadaan Codium sp. pada stasiun 3 lebih banyak dibandingkan dengan spesies lainnya. Dengan substrat yang berupa pasir dan karang mati menjadi habitat yang baik bagi alga hijau, sehingga kepadatan spesies pada semua stasiun penelitian didominasi oleh alga hijau.
Tingginya frekuensi kehadiran Halimeda disebabkan karena kemampuan adaptasi yang tinggi. Ira et al. (2018) menjelaskan, bahwa Halimeda memiliki yang serupa akar serabut yang dapat melekat pada serbagai jenis substrat, sehingga dengan kemampuan tersebut menjadikan Halimeda memiliki sebaran yang luas. Selain itu, Blaxteret al. (1980) dalam Arfah dan Patty (2016) menjelaskan, bahwa genus Halimeda merupakan salah satu genus pionir pertumbuhan makroalga pada suatu perairan.

\section{Keanekaragaman Spesies}

Gambar 3 menjelaskan bahwa Nilai indeks keanekaragaman spesies pada ketiga stasiun penelitian ini menunjukkan bahwa tingkat keanekaragaman spesies pada semua stasiun penelitian berada pada tingkat keanekaragaman yang sedang.Rendahnya 
indeks keanekaragaman spesies pada stasiun 1 di kawasan ini disebabkan oleh sempitnya zona intertidal. Menurut Ferawati et al. (2014), rendahnya nilai indeks keanekaragaman banyak disebabkan oleh kompleksitas habitat akibat kerusakan substrat atau gelombang tinggi. Faktor lain yang menyebabkan rendahnya keanekaragaman adalah aktivitas manusia yang berlebihan.
Indeks keanekaragaman spesies yang diperoleh dipengaruhi oleh heterogenitas substrat. Kestabilan, kekerasan, tekstur dan porositas substrat penting artinya bagi pertumbuhan makroalga yang mendukung kelimpahanya (Herlinawati et al., 2018).

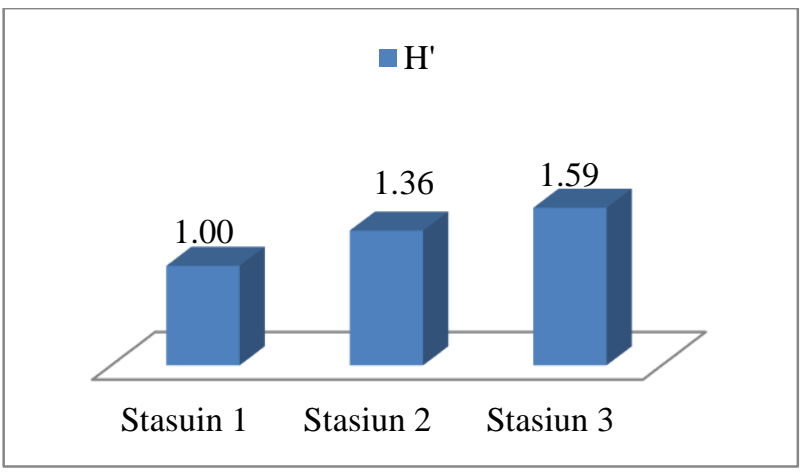

Gambar 3. Nilai Indeks Keanekaragaman Spesies makroalga Antar Stasiun pada lokasi penelitian.

\section{Keseragaman Spesies}

Indeks keseragaman spesies pada masing-masing stasiun termasuk dalam kategori sedang sampai tinggi. Tinggi rendahnya nilai indeks keseragaman pada tiap stasiun berhubungan erat dengan indeks keanekaragaman yang diperoleh pada tiap stasiun. Dalam penelitian ini, nilai indeks keseragaman spesies berbanding lurus dengan nilai indeks keanekaragaman spesies (Gambar 4). Nilai indeks keseragaman spesies ini dapat menunjukkan kondisi suatu perairan. Nilai indeks keseragaman yang tinggi menunjukkan kondisi perairan yang stabil. Sejalan dengan pendapat Syari (2005) dalam Rosdiana et al. (2017) menyatakan apabila suatu perairan memiliki indeks keseragaman spesies (E) $>$ 0,6 maka perairan tersebut berada dalam kondisi yang stabil dan keseragaman yang tinggi.

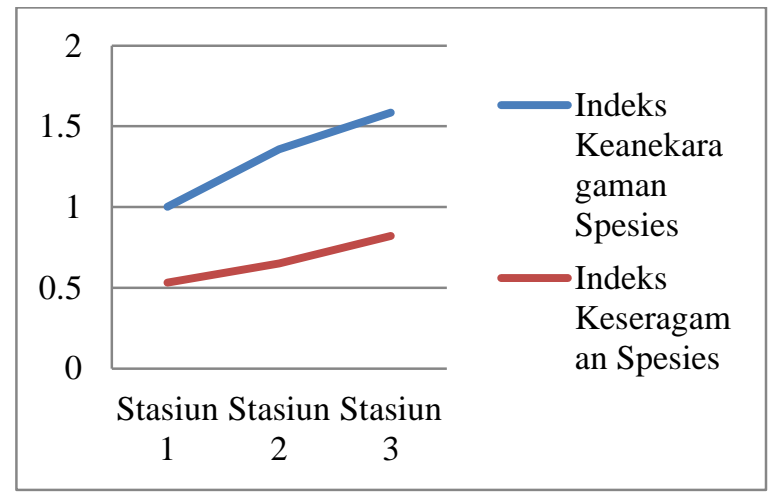

Gambar 4. Nilai Indeks Keanekaragaman dan Keseragaman Spesies Makroalga di lokasi penelitian

\section{Dominansi Spesies}

Rosdiana et al. (2017) menjelaskan, bahwa keanekaragaman suatu komunitas memiliki kaitan yang erat dengan tingkat dominansi organismenya. Apabila terdapat organisme dengan tingkat dominansi rendah maka keanekaragamannya menjadi tinggi. Data penelitian menunjukkan bahwa tidak ada spesies makroalga yang mendominansi pada lokasi penelitian. Nilai indeks dominasi yang diperoleh tidak mencapi 1. Oleh karena itu, katagorinya adalah rendah. Hasil pengukuran nilai indeks dominasi dan komparasinya dengan nilai indeks keanekaragaman spesies secara lengkap disajikan pada (Gambar 5).

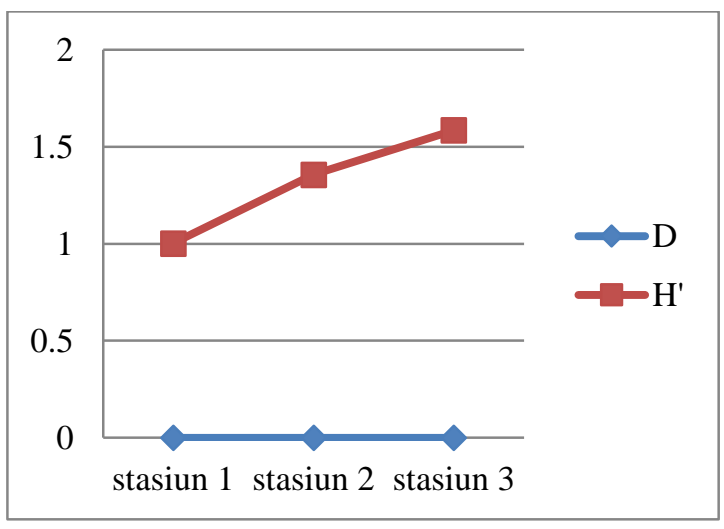

Gambar 5. Nilai Indeks Keanekaragaman dan Indeks Dominansi Spesies Makroalga di Perairan Gili Sulat. 


\section{Hubungan Faktor Lingkungan Dengan Populasi Makroalga}

Tabel 4 menunjukkan hasil uji korelasi antara faktor lingkungan dan komunitas makroalga bahwa ada hubungan korelasi yang positif antara salinitas dan suhu terhadap makroalga dengan nilai 0,65 dan termasuk kategori kuat. Sedangkan hasil perhitungan korelasi antara $\mathrm{pH}$ terhadap makroalga memiliki korelasi yang negatif dengan nilai $-0,98$ dan termasuk dalam kategori sangat kuat. Hal ini menunjukkan bahwa populasi makroalga sangat dipengaruhi oleh salinitas, $\mathrm{pH}$ dan suhu perairan.

Tabel 4. Hasil uji korelasi "r" Product Moment.

\begin{tabular}{lrc}
\hline \multicolumn{1}{c}{$\begin{array}{c}\text { Faktor } \\
\text { Lingkungan }\end{array}$} & $\begin{array}{c}\text { Koefisien } \\
\text { Korelasi }\end{array}$ & Kategori \\
\hline $\begin{array}{l}\text { Salinitas } \\
32 \% \text { o }\end{array}$ & 0,65 & Kuat \\
pH 7,6 & $-0,98$ & Sangat kuat \\
Suhu $27^{\circ} \mathrm{C}$ & 0,65 & Kuat \\
\hline
\end{tabular}

\section{Kesimpulan}

Kekayaan spesies makroalga di kawasan perairan Gili Sulat terdiri dari 11 spesies, 7 spesies dari kelas Chlorophyceae dan 4 spesies dari kelas Phaeophyceae. Halimeda opuntia adalahspesies dengan kepadatan tertinggi sebesar 18.519 rumpun/ha. Indeks keanekargaman spesies berkisar antara 1,00-1,59 dan termasuk dalam kategori keanekaragaman sedang. Indeks keseragaman spesies pada stasiun 1 dan 2 termasuk kategori sedang dengan nilai 0,53 dan 0,65 . Sedangkan pada stasiun 3 termasuk keseragaman tinggi dengan nilai 0,82 dan tidak ada spesies yang mendominasi di lokasi penelitian.

\section{Ucapan Terima kasih}

Tim pnelitian menyampaikan ucapan terima kasih kepada Dekan FKIP Universitas Mataram yang telah memberikan fasilitas laboratorium untuk pelaksaan penelitian.

\section{Daftar Pustaka}

Aini, Y.Q., A. Al Idrus \& L. Japa (2018). Komunitas Plankton Pada Perairan Habitat Mangrove Di Gili Sulat Lombok Timur. Prosiding Seminar Nasional Pendidikan Biologi, 1(1): 32-40. http://www.jurnalfkip.unram.ac.id/index.php/Se mnasBIO/article/viewFile/616/564
Al Idrus, A. (2014). Mangrove Gili Sulat Lombok Timur. Lombok Barat: Arga Puji Press. https://scholar.google.co.id/scholar?hl=id\&as_s $\mathrm{dt}=0 \% 2 \mathrm{C} 5 \& \mathrm{q}=$ Mangrove + Gili+Sulat+Lombok +Timur

Al Idrus, A., I.G. Mertha, G. Hadiprayitno \& M.L. Ilhamdi (2014). Kekhasan Morfologi Spesies Mangrove Di Gili Sulat. Jurnal Biologi Tropis, 14(2): 120-128. DOI 10.29303/jbt.v14i2.139

Al Idrus, A., G. Hadiprayitno, I.G. Mertha \& M.L. Ilhamdi (2015). Potensi Vegetasi Dan Arthropoda Di Kawasan Mangrove Gili Sulat Lombok Timur. Jurnal Biologi Tropis, 15(2): 183-196.

DOI: http://dx.doi.org/10.29303/jbt.v15i2.206

Arikunto, S. (2018). Dasar-Dasar Evaluasi Pendidikan. Jakarta: Rineka Cipta. https://scholar.google.co.id/scholar?hl=id\&as_sd $\mathrm{t}=0 \% 2 \mathrm{C} 5 \& \mathrm{q}=$ Dasar-

Dasar+Evaluasi+Pendidikan.+\&btnG

Arfah, H. \& S.I. Patty (2016). Kualitas Air dan Komunitas Makroalga di Perairan Pantai Jikumerasa, Pulau Buru. Jurnal Ilmiah Platax, 4(2): 209-119. https://pdfs.semanticscholar.org/f3e1/562e56d1 b6e9b2ac99f43c6551588ea61195.pdf

Bachtiar, I. (2005). Integrating Formaland Customary Approaches to Responsible Fisheries: A CaseStudy of District Fisheries Services in Nusa Tenggara Barat Province, Lombok, Indonesia. Fish for the People, 2(3): 41-45. http://hdl.handle.net/20.500.12066/705

Erliyanda., M.A. Sarong \& C. Octavina (2017). Kepadatan Dan Keanekaragaman Meiofauna Di Perairan Sungai Meureudu Kecamatan Meureudu Kabupaten Pidie Jaya. Jurnal Ilmiah Mahasiswa Kelautan dan Perikanan Unsyiah, 2(1): $\quad$ 26-32. https://www.neliti.com/publications/188233

Ferawati, E., D. S. Widyartini \& I Insan (2014). Studi Komunitas Rumput Laut Pada Berbagai Substrat di Perairan Pantai Permisan Kabupaten Cilacap. Scripta Biologica, 1(1):55-60. DOI: 10.20884/1.sb.2014.1.1.25

Hadiprayitno, G., A. Al Idrus, M.L. Ilhamdi \& I.G. Mertha (2014). Keanekaragaman Jenis Burung Di Kawasan Mangrove Gili Sulat Lombok Timur. Proceeding Biology Education Conference: 
Biology, Science, Enviromental, And Learning, 11(1): $\quad$ 448-452. https://jurnal.uns.ac.id/prosbi/article/view/7784

Herlinawati, N.D.P.D, I.W. Arthana \& A.P.W.K. Dewi. (2018). Keanekaragaman dan Kerapatan Rumput Laut Alami Perairan Pulau Serangan Denpasar Bali. Journal of Marine and Aquatic Sciences, 4(1), 22-30. DOI: https://doi.org/10.24843/jmas.2018.v4.i01.22$\underline{30}$

Ira., Rahmadani \& N. Irawati (2018). Komposisi Jenis Makroalga di Perairan Pulau Hari Sulawesi Tenggara. Jurnal Biologi Tropis, 18 (2) :141 158.

DOI:

http://dx.doi.org/10.29303/jbt.v18i2.770

Karnan, Al Idrus, A. \& Japa, L. (2016). Laju Pertumbuhan Sargassum yang Dibudidaya di Teluk Ekas Lombok Timur. Prosiding Seminar Nasional Pertanian Universitas Mataram, 12 November 2016. https://scholar.google.co.id/scholar?hl=id\&as_s $\underline{\mathrm{dt}=0 \% 2 \mathrm{C} 5 \& \mathrm{q}=\text { Laju}+ \text { Pertumbuhan }+ \text { Sargassum }}$

Karnan, D. Santoso, L. Japa \& A. Raksun (2018). Makroalga di Daerah Intertidal Pulau Lombok Selatan. Jurnal Biologi Tropis, 18 (1): 109-122. DOI: http://dx.doi.org/10.29303/jbt.v18i1.738

Kementerian Kelautan dan Perikanan (2013). Informasi kawasan konservasi perairan indonesia. Jakarta. Kementerian Kelautan Dan Perikanan. https://scholar.google.co.id/scholar?hl=id\&as_s $\mathrm{dt}=0 \% 2 \mathrm{C} 5 \& \mathrm{q}=$ Informasi+kawasan+konservasi +perairan

Kementerian Kelautan dan Perikanan (2016). Laporan Kinerja Kementerian Kelautan Dan Perikanan 2015. Jakarta. Kementerian Kelautan Dan Perikanan.

https://scholar.google.co.id/scholar?hl=id\&as_s $\mathrm{dt}=0 \% 2 \mathrm{C} 5 \& \mathrm{q}=$ Laporan + Kinerja + Kementerian $\underline{+ \text { Kelautan }}$
Krebs, C.J. (1972). Ecology: The Experimental Analysis Of Distribution And Abundance. New York: Harper \& Row. https://scholar.google.co.id/scholar?hl=id\&as_sd $\mathrm{t}=0 \% 2 \mathrm{C} 5 \& \mathrm{q}=\mathrm{The}+$ Experimental + Analysis $+\mathrm{Of}+$ Distribution

Lazuardi, M.E. (2013). Challenges of Marine Protected Areas around Lombok, Indonesia. Australia: James Cook University. https://www.researchgate.net/profile/Muhamma d_Lazuardi/publication/292893615_Challenges _of marine protected areas_around_Lombok_I ndonesia/links/56b1c0a808ae795dd5c5e2d9.pdf

Palallo, A. (2013). Distribusi Makroalga Pada Ekosistem Lamun Dan Terumbu Karang Di Pulau Bonebatang Kecamatan Ujung Tanah Kelurahan Barrang Lompo Makassar. Skripsi.Program Studi Ilmu Kelautan. Fakultas Ilmu Kelautan Dan Perikanan Universitas Hasanuddin. Makassar. https://scholar.google.co.id/scholar?hl=id\&as_s $\mathrm{dt}=0 \% 2 \mathrm{C} 5 \& \mathrm{q}=$ Distribusi + Makroalga + Pada $+\mathrm{Ek}$ osistem+Lamun+Dan+Terumbu+Karang+Di+P ulau+Bonebatang+Kecamatan+Ujung+Tanah+ $\underline{\text { Kelurahan+Barrang+Lompo+Makassar\&btnG }}$

Rahmandi, R. (2019). Struktur Komunitas Makroalga Di Kawasan Intertidal Pantai Mandalika Lombok Tengah. Skripsi.S1 Pendidikan Biologi. FKIP Universitas Mataram. Mataram. http://www.jurnalfkip.unram.ac.id/index.php/S emnasBIO/article/view/652

Nurgayah, W. (2018). Struktur Komunitas Makroalga Di Perairan Waworaha Kecamatan Soropia. Jurnal Sapa Laut (Jurnal Ilmu Kelautan), 2(3). http://ojs.uho.ac.id/index.php/JSL

Sugiyono (2018). Metode Penelitian Pendidikan Pendekatan Kuantitatif, Kualitatif dan $R \& D$. Bandung: Alfabeta. https://scholar.google.co.id/scholar?hl=id\&as_sd $\mathrm{t}=0 \% 2 \mathrm{C} 5 \& \mathrm{q}=$ Metode + Penelitian + Pendidikan $+\mathrm{P}$ endekatan 